\title{
Where The Boys Are, Post Covid-19: Shifting the Special Education and Out-of-School Suspension Narrative for Boys of Color
}

\author{
Aresta L. Johnson, Kimberly Fitchett-Bazemore \\ Elizabeth City State University, Elizabeth City, North Carolina, United States
}

\begin{abstract}
Far too long United States educational systems grappled with the stark disproportionality of boys of color over-identified for special education and the disproportionate rate of school suspensions and arrest. Under President's Biden's Covid relief plan, school districts have garnered fiscal support of unimaginable proportions, yet plans to readily address the ills impacting boys of color have yet to be fully developed or discussed in school districts. Post pandemic provides an opportunity for school districts and communities to galvanize their collective efforts to re-examine the disproportionality which continues to exist amongst boys in color identified for special education services.
\end{abstract}

Keywords: special education, boys of color, individualized education plan; out-of-school suspension 


\section{Introduction}

An Individualized Education Plan (IEP) is a written plan that provides instruction, support, and services for students with disabilities. Key issues with the IEP's have been uncovered over time, such as student engagement and validation, teacher competency, and IEP execution, particularly during the pandemic. The IEP clarifies the student's accommodation, modifications, and special education goals (Nolan-Spohn, 2016). With the use of an IEP, identified students are directed towards the regular classroom setting within the Least Restrictive Environment (LRE). Schools often initiated the Planning and Placement Team (PPT) meeting toward specifics of the school's improvement plan, goals, and guidelines, were often void of parallel alignment to the student's IEP objectives. PPT meetings are scheduled in the middle of the day, which means that the parent(s) will need to miss work. It can be an intimidating meeting that includes the principal, psychologist, social worker, special coordinator, and classroom teacher (Kunjufu, 2013).

Student engagement and validation of their IEP aided students towards obtaining selfdetermination skills and independence. Inclusion of the student also leads to a deeper understanding of the IEP accommodations. The students have a better understanding of the IEP accommodations developed specifically to address their learning disability (Nolan-Spohn, 2016). Pounds and Cuevas (2019) found that this exchange provided students with the opportunity to voice their own opinions towards the development and implementation of their own life goals. Martin (2004) conducted a three-year study of 383 PPT meetings and found that students were the least informed member of the team, with the teacher being the next least informed participant. Considering the dynamics of special education and its role in the educational process, this is exponentially damaging when these labels are placed upon marginalized subgroups, particularly boys of color.

\section{Location}

Suburban school districts are well positioned to receive a surplus of funding through local tax streams to support educational initiatives, such as curriculum development, human capital bargaining unit increases, special education, and capital improvement planning. This often leaves large urban districts at a disadvantage, as these locales have a superfluous number of issues beyond the boundaries of educational, human capital, and capital improvement planning. Williams-Diehm et al. (2014) explored whether living in a rural, suburban, or urban 
areas impacted parent and student participation in the development of student IEP's. The study utilized a quantitative survey with two open-ended questions to determine the level of participation among parents and students in IEP's development. The findings showed that students in rural areas were more involved in the development of their IEP's than students in urban or suburban areas. There was a minor variation in the level of parental participation regardless of locality.

\section{Cultural Diversity and Minorities}

Lo (2012) examined from a quantitative approach, two parents from diverse cultural backgrounds and their IEP meeting experience. In this study, parents struggled with understanding the educational jargon, acronyms, and protocols highlighted and noted an overall lack of support from the school. For example, one parent had a school sponsored interpreter who did not speak the same dialect. The lack of an interpreter spoke to the need to have adequate training for school leaders and central office staff, along with the statemandated requirements for providing the appropriate interpreting staff for parents. While this level of support requires the district to be fiscally responsible, shortcuts are at the detriment of the student. As such, national organizations are on the rise, ensuring that districts are being held accountable for providing the legally mandated support systems for parents advocating to be intimately involved in their child's educational process. Furthermore, the study noted a lack of cultural understanding that significantly impeded the educational success of students. Lo's (2021) study humanized the IEP process and amplified the long-term impact of ineffective PPT meetings places upon the family, and the successful outcomes of the students for whom the IEP was developed. Rios (2020) conducted a qualitative study based upon the issues facing the Latino community and the development process of IEPs. The study found that Latino mothers had felt stressed prior, during, and after the IEP meetings, and received minimal support from spouses or the school.

\section{Student Involvement in IEP's}

Pounds \& Cuevas (2019) conducted a study to determine the impact of student involvement in the IEP process and its impact upon achievement of IEP goals, academic success, and the effective implementation of IPLAN, a self-advocacy strategy, in the IEP process. The results 
from this study determined that there was a significant positive impact upon academic achievement when students were involved in the PPT. When students of non-English speaking parents served in the capacity of translator for their parents, as well as the advocator for their educational goals identified in the IEP, this places an undue burden upon the student. While this is not considered best practice, it does occur, primarily in large, fiscally challenged school districts. Nolan-Spohn (2016) noted the importance of individual student IEP preparation conferences, which included explaining the process and reviewing items that would be discussed at the Pupil Planning Team (PPT)meeting. This is a strategy that builds the student's confidence and is a practice deemed worthy of duplication on the national educational landscape.

\section{Over-Identification}

Boys of color receiving special education services continue to be overrepresented in terms of numbers compared to boys of other races. Boys of color, as early as preschool, face overidentification to special education, as well as a perceived level of low and negative expectation from teachers (Wright \& Ford, 2019). Male students of color are commonly overidentified in the special education system (Grindal et al., 2019). This belief has led to civil rights litigation and amendments to educational policy (Morgan, Farkas, et al., 2017). Grindal et al. (2019) aimed to understand the impact that income and race have on special education identification. Farkas et al. (2020) further examines special education racial risks with potential explanations in the achievement gaps. Regression data results represented the correlation between the risks in minorities and whites in special education. The research found that the overrepresentation in special education for minority students is explained by racial achievement gaps (Farkas et al., 2020). Many influential factors outside of the school impact social inequities. When the achievement gap is larger, students experience lower quality health care, and this can result in lack of support and services for underrepresented children of color in special education (Morgan et al., 2017).

PPT meetings need to accommodate the parents and students, as opposed to the school and district. Some of the professionals will recommend more right-brained lessons such as visual aids, verbal skills, tactile, and kinesthetic learning as interventions prior to referral, however, the professionals do not always agree and sometimes it is easier to go with the majority (Kunjufu, 2013). A more sensible and compassionate approach is the creation of a pre-referral 
intervention team of Master Teachers that some schools are now implementing (Kunjufu, 2013).

\section{Out-of-School Suspension}

African American students are far more likely, than white students, to be disciplined with an out-of-school suspension (OSS) disciplinary consequence. In North Carolina, according to the National Center for Education Statistics (NCES) in 2013-2014 reports that 13.42\% of African American boys were suspended and $3.77 \%$ of white males were suspended. African American boys are four times more likely to be suspended than girls (Huang, 2016). Out of school suspension and expulsion pushes children out of school and into the juvenile justice system, with harsher penalties for males of color and of lower socioeconomic status (Mizel et al., 2016). Teachers need to be creative in teaching the curriculum to the individual learning styles of their students, keeping them engaged, and excited about learning. Students who are left to their own devices tend to find other distractions within or outside of the schoolhouse. As a result of their disengagement with instruction they display behaviors that are disruptive to the classroom environment. Having classrooms that are conducive to boys is another approach. Adding recess every day, letting students stand at the table, and shoot a basket if a question is answered correctly, having movement between centers, using kinesthetic learning, small group discussion, debates and a dynamic culturally centered classroom which inspires critical thinking are all things that can help keep students engaged and on task (Kunjufu, 2013). These disciplinary infractions also have economic impact upon the African American male, as it impacts the child and their family when boys of color are expelled and suspended from school (Mccray et al., 2015). Racial and ethnic disparities are a constant topic in the school system. Wegman and Smith (2019) noted the use of exclusionary discipline was particularly applied to the boys of color and that white teachers were more likely to view boys of color as aggressive and combative. Teachers, school administrators, and central office personnel must assess their cultural biases and incorporate culturally responsive training in the schools if we are to shift the narrative.

\section{Out of School Suspensions for Boys of Color Compared to Other Students}

At a time of increasing national concerns about racism, attention is being focused on the disciplinary procedures within schools across the nation, particularly, the discipline gap 
between boys of color and their counterparts. Research showed boys of color, compared to white counterparts, were three times more likely to be suspended (Cagle, 2017). This discipline gap was attributed to the achievement gap of students of color with lost instructional time due to suspensions (Pearman, Curran, Fisher, \& Gardella, 2019). Coles and Powell (2020) invited educators to confront antiblackness prior to doling our suspensions for males of color. Although disciplinary consequences are disproportional, Huang (2018) gathered high school disciplinary data and found offenses committed by black students did not occur as often as it did for white students. The disparities still exist, and the short-term and long-term outcomes are known. If this trend continues, the consequences will be dire. Educators, parents, communities, and policy makers must be compelled to implement positive, alternative interventions to the negative impacts of out-of-school suspensions. Out-of-school suspensions paralleled lower academic achievement and dropout rates (Skiba, Chung, Trachok, Baker, Sheya, \& Hughes, 2014). Studies showed that suspensions increased those students' chances of becoming incarcerated later in life (Riddle \& Sinclair, 2019). Davis (2017) noted, discipline policies must be discussed and improved to be consistent, studentstrength based, and non-discriminatory. Training and researched-based programs that support the needs of at-risk populations were needed as preventative alternatives to out-of-school suspensions (Davis, 2017). The disparity of out-of-school suspension rates reflected the urgent need for policy reform. The U.S. Departments of Justice and Education addressed this issue by recommending approaches that provide an alternative to current disciplinary programs (Skiba, Chung, Trachok, Baker, Sheya, \& Hughes, 2014).

\section{Conclusions}

Throughout this pandemic some institutions and schools have found it hard to execute IEPs due to virtual learning and social distancing. Studies have found that institutions or schools and teachers must rely on a student's family for distance learning to work effectively for all students including a special needs child. Teachers can accommodate all their students with the appropriate instructional resources, including those with special needs (Ayda et. al, 2020). Some teachers believed they lacked the proper understanding and knowledge required to fully support PPT's and academic modifications (Debbag, 2017). This makes them unqualified to create long-term and short-term goals and targets. The teachers believed additional support offered through the school district would assist in their career growth, skillset, and overall attitude regarding their practice. Scott (2012) noted, a teacher's confidence in their teaching 
leads to a student leading their IEP meetings and found that teachers who have a positive belief in their capacity to teach, have better results in special education students.

Resolutions to address the disparity in special education and out-of-school suspensions have been implemented across the country with significant success. Response to Intervention (RTI) is a framework designed to support students of color and students with learning disabilities, and to increase student achievement and reduce the achievement gap. Implementing this framework includes all students and provides differentiated instruction to provide greater support and instructional time for students that can benefit from it (Cohen et al., 2015).

The United States Department of Justice Civil Rights Office issued remedies in January 2014 consisting of twelve action items to address the disparity of out-of-school suspensions. Five of those remedies are as follows:

- Modifying disciplinary records for those who received biased sanctions

- $\quad$ Providing fiscal compensation for loss of learning due to sanctions

- $\quad$ Creating fair and consistent disciplinary policies

- $\quad$ Provide training in intervention strategies and discipline policies

- Designate a singular school official to ensure consistency of sanctions across the school campus

\section{References}

[1] Ayda, N. K., Bastas, M., Altinay, F., Altinay, Z., Dagli, G. (2020). Distance Education for Students with Special Needs in Primary Schools in the Period of CoVid-19 Epidemic. Journal of Educational Psychology 8(3). http://dx.doi.org/10.20511/pyr2020.v8n3.587

[2] Cagle, J.F. (2017). The cost of color in public education - An examination of disproportionate suspensions. Journal of Organizational \& Educational Leadership, 3(1). https://digitalcommons.gardner-webb.edu/joel/vol3/iss1/3/

[3] Cohen, D. R., Burns, M. K., Riley-Tillman, C., \& Hosp, J. L. (2015). Are minority students under- or overrepresented in special education? National Association of School Psychologists, $44(2)$, https://www.nasponline.org/publications/periodicals/communique/issues/volume-44issue- 2 
[4] Davis, C.R. (2017). Why are the black kids being suspended? An examination of a school district's efforts to reform a faulty suspension policy through community conversations. School Community Journal 27(1). https://files.eric.ed.gov/fulltext/EJ1146472.pdf

[5] Debbag, M. (2017). Opinions of Prospective Classroom Teachers About Their Competence for Individualized Education Program (IEP). Universal Journal of Education Research, 5(2), 181-185. DOI: 10.13189/ujer.2017.050202

[6] Farkas, G., Morgan, P. L., Hillemeier, M. M., Mitchell, C., \& Woods, A. D. (2020). District-level achievement gaps explain Black and Hispanic overrepresentation in special $\begin{array}{llll}\text { education. } & \text { Exceptional } & \text { 374-39), }\end{array}$ https://doi.org/10.1177/0014402919893695

[7] Grindal, T., Schifter, L. S., Schwartz, G., \& Hehir, T. (2019). Racial differences in special education identification and placement: Evidence across three states. Harvard Educational Review, 89(4), 525-553,700-702. https://doi.org/10.17763/1943-5045-89.4.525

[8] Huang, F. L. (2016). Do black students misbehave more? investigating the differential involvement hypothesis and out-of-school suspensions. The Journal of Educational Research, 111(3), 284-294. https://doi.org/10.1080/00220671.2016.1253538

[9] Kunjufu, J. (2013, June 30). Changing school culture for black males. ProQuest Ebook. Central. 71-76. https://ebookcentral-proquest-com.ecsu1891.idm.oclc.org

[10] Lo, L. (2012). Demystifying the IEP process for diverse parents of children with disabilities. Teaching Exceptional Children, 44(3) , https://doi.org/10.1177/004005991204400302

[11] Martin, J.E., Huber Marshall, L. \& Sale, P. (2004). A 3 -year study of middle, junior high, and high school IEP meetings. Exceptional Children, 70(3), 285-297. https://doi.org/10.1177\%2F001440290407000302

[12] Mccray, C. R., Beachum, F. D., \& Yawn, C. D. (2015). Saving our future by reducing suspensions and expulsions among African American males. Journal of School Leadership, 25(2), 345-367. https://doi.org/10.1177/105268461502500206

[13] Mizel, M. L., Miles, J. N. V., Pedersen, E. R., Tucker, J. S., Ewing, B. A., \& D'Amico, E. J. (2016). To educate or to incarcerate: Factors in disproportionality in school discipline. Children and Youth Services Review, 70, 102-111. https://doi.org/10.1016/i.childyouth.2016.09.009 
[14] Morgan, P.L., Farkas, G., Cook, M., Strassfeld, N.M., Hillemeier, M. M., Pun, W.H., \& Schussler, D. L. (2017). Are black children disproportionately overrepresented in special education? A best-evidence synthesis. Exceptional Children, 83(2), 181-198. https://doi.org/10.1177/0014402916664042

[15] Morgan, P. L., Woods, A. D., Wang, Y., Hillemeier, M. M., Farkas, G., \& Mitchell, C. (2020). Are schools in the U.S. south using special education to segregate students by race? Exceptional Children, 86(3), 255-275. https://doi.org/10.1177/0014402919868486

[16] National Center for Education Statistics (2018). Digest of Education Statistics, 2018. (n.d.). https://nces.ed.gov/programs/digest/d18/tables/dt18 233.40.asp.

[17] Nolan-Spohn, H. (2016). Increasing Student Involvement in IEPs. Mid-Western $\begin{array}{lll}\text { Educational } \quad \text { Researcher, } & \text { 300-308. }\end{array}$ https://www.mwera.org/MWER/volumes/v28/issue3/v28n3-Nolan-VOICES-FROM-

\section{THE-CLASSROOM.pdf}

[18] Pearman, F.A., Curran, C.F., Fisher, B., Gardella, J. (2019). Are achievement gaps related to discipline gaps? Evidence from national data. Sage Journal, 5(4). https://doi.org/10.1177\%2F2332858419875440

[19] Pounds, L., Cuevas, J. (2019). Student involvement in IEPs. Georgia Educational Researcher, 16 (1), 23-47. Retrieved from https://files.eric.ed.gov/fulltext/EJ1206045.pdf

[20] Rios, K., Aleman-Tovar, J., \& Burke, M.M. (2020). Special education experiences and stress among Latina mothers of children with autism spectrum disorder (ASD). Research in Autism Spectrum Disorders, 73. https://doi.org/10.1016/j.rasd.2020.101534

[21] Scott, L. (2012). Teacher self-efficacy with teaching students to lead IEP meetings: A correlation study on administrator support. I-Manager's Journal on Educational Psychology, 5(3), 9-20. https://doi.org/10.26634/jpsy.5.3.1655

[22] Skiba, R.J., Choong-Geun, C., Trachok, M., Baker, T.L., Sheya, A., Hughes, R.L. (2014). Parsing disciplinary disproportionality: Contributions of infraction, student, and school characteristics to out-of-school suspension and expulsion. American Education Research Journal, 51(4). https://doi.org/10.3102\%2F0002831214541670

[23] United States Department of Justice, Civil Rights Division and the U.S. Department of Education, Office of Civil Rights (2014, January 8). Joint Colleague Letter: Nondiscriminatory Administration of School Discipline. https://www2.ed.gov/about/offices/list/ocr/letters/colleague-201401-title-vi.html 
[24] Wegmann, K. M., \& Smith, B. (2019). Examining racial/ethnic disparities in school discipline in the context of student-reported behavior infractions. Children and Youth $\begin{array}{lll}\text { Services } & \text { Review, } & 18-27 .\end{array}$ https://doi.org/https://doi.org/10.1016/j.childyouth.2019.05.027

[25] Williams-Diehm, K., Brandes, J. A., Chesnut, P. W., \& Haring, K. A. (2014). Student and parent IEP collaboration: A comparison across school settings. Rural Special Education Quarterly, 33(1), 3-11. https://www.proquest.com/docview/1521943202?accountid=10717

[26] Wright, B. L., \& Ford, D. Y. (2019). Remixing and reimagining the early childhood school experiences of brilliant black boys. Boyhood Studies, https://doi.org/10.3167/bhs.2019.120103 